\title{
神経因性耪睄の OAB
}

\section{猫協医科大学医学部泌尿器科}

山西 友典, 吉田 謙一郎

神経因性膀腅の $\mathrm{OAB}$ の原因は、脳疾患、脊髄疾患で、通常神経因性排尿筋過活動 (neurogenic detrusor overactivity: NDO) によるものである。NDO とは、神経因性膀胱に伴った排尿笳過活動（従来排尿筋過反射と呼ばれていたもの）と 定義される。脳疾患による神経因性膀胱は、非神経因性 $\mathrm{OAB}$ と同様に尿意切迫感を伴う事が多く、特に高齢者の特発性 $\mathrm{OAB}$ と診断されるものの中には潜在性脳疾患（多発性脳梗塞など）が原因と考えられる場合も多い。脊䯣疾患、特に脊 髄損傷の場合では、尿意が不明膫で、必ずしも尿意切迫感を伴うとは限らない。したがって厳密な意味では過活動膀胱 $(\mathrm{OAB})$ に入らない場合もあるが、病態としては $\mathrm{OAB}$ と同様の排尿筋過活動 (DO) に基づくものであり、治療も $\mathrm{OAB}$ と 同様である。しかし NDO に扔いては、OABに特徴的な蓄尿障害のみでなく、排出障害を合併していることも稀ではない。 NDO の診断・治療は尿流動態検查に基づいて行う必要がある。本シンポジウムにおいて、神経因性膀胱の種々の神経疾 患における尿流動態検查の特徵を概説する。特に脊䯣疾患によるNDOにおいては、排尿筋 - 外尿道括約協調不全 (DSD) を伴っている場合は高圧排尿となり、上部尿路損傷などの合併症をきたす危険があるので、その治療にあたっては、蓄尿、 排出両障害の治療を目指すのと同時に合併症を予防するための排尿管理が必要で, バランス膀胱をめざした治療を行う。 治療法には、OAB の一般的な保存療法、すなわち 1) 行動療法:生活指導、理学療法（骨盤底筋訓練やバイオフィードバッ ク訓練)、計画療法（膀胱訓練）、2）抗コリン薬を中心とした薬物療法などの一般的な治療法のほかに、神経因性膀胱 に打ける難治性、重症の $\mathrm{OAB}$ に対し、3）バニロイド（レジニフェラトキシン、カプサイシン）の膀胱内注入療法、4） ボツリヌストキシン膀胱壁内注入療法、5) Neuromodulation/電気・磁気刺激療法などがある。さらなる重症例に対しては、 膀脱拡大術などの手術療法も適応とされる。

\section{S9-5}

\section{貛治性夜尿症小児における排尿時ウロダイナミクス}

\author{
自治医科大学とちぎ子ども医療センター泌尿器科 \\ 中井 秀郎
}

難治性夜尿症の男児に対する排尿時膀胱尿道造影（以下V C U G）は、原因疾患としての先天性下部尿路奇形を診断するために重要である。 代表的な原疾患として後部尿道弁が挙げられるが、乳幼児期の重症後部尿道弁とは梯相を異にして、典型的な症例以外は画像による病変診断 が暧昧なことも多い。全身麻酔下の内視鏡診断を行うか、それでもハッキリしない場合は、内視鏡切開（さいわいに手術侵襲が低い）を施行 して、造影所見や排尿症状の改善などにより結果的に尿道通過障害を診断する、ということが、現在までしばしば行われてきた。

より効率的な下部尿路閉塞の診断、難治性夜尿症の治療には、小览の排尿時ウロダイナミクス（随意排尿中の排尿筋圧、尿流率、外尿道括約 筋筋電図の持続測定と記録）の導入が重要と考六、体格を考慮したカテーテルサイズの物理的問題、排尿時違和感によるアーテイファクトの 問題、小児ゆえの検查協力可否の問題などに対して工夫を加えつつ研究を行った。

中心静脈用 $18 \mathrm{G}$ ダブルルーメンカテーテルを用い、膀羘内圧測定に引き続いての排尿時ウロダイナミクスを 1 回の検査につき 3 回以上行っ

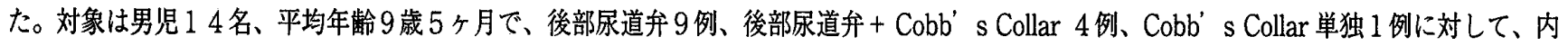
視鏡切開を加えた前後のVCUG像、排尿時ウロダイナミクス所見、夜尿症状 (NE症状)·過活動膀胱症状 (OAB 症状) の改善度を評価した。 この結果、1）排尿筋圧は、14 例中 5例で、排尿中ではなく排尿直前に最大值を示した。これらのうち、内視鏡切開によって、NE症状、 $O A B$ 症状のいずれかが反応を示した症例は存在しなかった。2）上記の症例を除く9例では、内視鏡切開は、6名のNE症状の改善、7名 の OAB 症状の改善に有効であった。3）排沓中の最大排尿筋圧が、90 cm 水柱を越える 4 症例では、内視鏡切開により 3 例で $\mathrm{NE}$ 症状が 改善し、4例全例で OAB 症状が改善した。

以上は、難治性夜尿症小児に対する排尿時ウロダイナミクスが、内視鏡切開後の治療成績に関連することを示したものであり、排尿時ウロダ イナミクスにより、今後、内視镜治療の適応がより明確に判断できるようになると考えられる。このことは同時に、難治性夜尿症男览に拀け るV C U G 異常尿道所見が器質的閉塞によるものだけではなく、機能的閉塞による可能性もあることを示唆しているのではないかと考えられ た。 